\title{
Review
}

\section{Problemy zmiany konstytucji, scientific editor Ryszard Chruściak, Sejm Publishing House, ISBN 978-83-7666-476-7, Warsaw 2017, pp. 309}

At the twentieth years' anniversary of validity of the Third Republic Constitution a political and scientific discussion has started with a new intensity around the need, or even a necessity, to make changes in it or simply to adopt a quite new Polish Basic Law. Various initiatives multiply to collect opinions, to poll citizens, or more specialist ones to poll lawyers constitutionalists. Representatives of the state bodies, some political parties, non-governmental organisations encourage to evaluate the Constitution of 2 April 1997 and submit proposals for correction of the solutions adopted in it. A very good starting point for comprehensive considerations on this subject can be reading of the monograph Problemy zmiany konstytucji prepared by the editor Ryszard Chruściak.

This author for many years has tracked, documented, analysed and made popular pending constitutional work in Poland. We owe him a number of papers, to which every researcher of the contemporary Polish constitutionalism must reach. It is enough to mention even several titles: Projekty konstytucji, 1993-1997. Cz. 1 and Cz. 2, Warsaw 1997, Przygotowanie Konstytucji Rzeczypospolitej Polskiej z dnia 2 kwietnia 1997 r.: przebieg prac parlamentarnych, Warsaw 1997, Sejm i Senat w Konstytucji RP z 1997 r. Powstawanie przepisów, Warsaw 2002, Prace konstytucyjne w latach 1997-2007, Warsaw 2009, Prace konstytucyjne w latach 2008-2011, Warsaw 2013.

This time Ryszard Chruściak is the scientific editor and simultaneously the co-author of the book, in which nine lawyers constitutionalists on the back- 
ground of drafts and proposals for constitutional regulations (both formally submitted, as well as informal ones, both complete and partial ones) which have come out since passing the Constitution in 1997 till the end of the $7^{\text {th }}$ term of Sejm in 2015 (the Editor underlines that all elaborations have arisen before the beginning of the 7th parliamentary term) three problems were taken. Each of them was covered in the separate chapter.

In the first one R. Chruściak preparing a kind of basis for reflections of other Authors performs a substantive review of the formally submitted draft amendments to the Basic Law and other proposals for changes of it. He describes these initiatives (just two), which turned to be effective, the drafts formally submitted to Sejm but not passed, drafts prepared by the parliamentary clubs and the Sejm commissions not submitted as legislative initiatives and these, which also were not directed to Sejm formally but were prepared outside parliament (drafts for amendments, but as well 10 comprehensive drafts of the Constitution).

In the same chapter Maria Kruk not performing the evaluation of amendment drafts of the Constitution carries out the detailed classification using as many as six criteria of division. From a subjective point of view she highlights the drafts, which were formally submitted, published or sponsored by: political parties, state bodies (institutions), social entities (i.e. social institutions, personalities of public life, media, public opinion among others groups of citizens), and the doctrine (experts). According to the criterion of most often emerging in the initiatives categories of matters, she distinguished proposals concerning: axiology and basic principles, system of government, other authorities, rights and freedoms and these, which concerned issues related to the participation of the Republic of Poland in the European integration. Dividing the drafts from the point of view of the scope of the proposed amendments she indicated these, which are comprehensive drafts (new constitutions), these of a considerable scope and these, which relate to only specified legal institutions (individual, sometimes even single provisions). Applying the criterion formally the Author of this part of the monograph divided the drafts into these which came from the entities having the right of the legislative initiative and these which do not have it and drafts bills passed and rejected. At the end she distinguished such amendments, which she considers to be objectively necessary and these, which are not necessary in her opinion. 
The second part of the book consists of three papers concerning the system of government. Jarosław Szymanek followed up this thread of the constitutional discussion, which concerns the relation, as he himself defined, "in the triangle government - parliament - president", rightly pointing that it is "almost always one of the main subjects of desirable or even necessary changes and all kinds of constitutional amendments" (p. 107). The analysis which was performed by him led to the conclusion that a direction of a possible amendment of the system of government "should not and - in the foreseeable time perspective - will not reverse the tendency to build the parliamentary system, however, amended, this is rationalised one, it means assuming the effective executive power subject to equally effective parliamentary control" (p. 164).

Jerzy Jaskiernia discussed the construction of dualism of the executive in coming from 2010 drafts of Platforma Obywatelska and Prawo i Sprawiedliwość, as well as in drafts prepared in 2009 in the Ombudsman's Office and in the scope of the Seminar Experience and Future. He decided that: "This analysis would not be clear, if the issues of duality genesis of the executive were omitted in the RP structural system and motivations, which have determined to reach for this system". In his opinion: "One should also refer to the solutions contained in the RP Constitution, and also to the practise of the system, which was formed on its basis" (p. 169). The background for considerations outlined in this way the and research itself of the mentioned drafts persuaded the Author to a reflexion that they "do not strive de lege fundamentali ferenda for the basic questioning the construction of the executive duality contained in the RP Constitution RP. However, they may lead to its clarification or enrichment" (p. 203).

The subject of the third paper of the second part of the discussed book is analysis of the author Jerzy Kuciński concerning five drafts of the constitution containing in his opinion "aiming, although in a different way, at a direction of the presidential system of government" (p. 206). These are the drafts of: Samoobrona from 2004, one of drafts presented by the Ombudsman in 2009, the draft presented by Solidarna Polska in 2013, and two drafts by Prawo i Sprawiedliwość from 2005 and 2010. Transformations leading to the presidential system of government were to rely on strengthening of the legal status of the RP President, changes in the mode of his election, extension of competences and resolving again matters concerning official acts of the President. In the conclusion the Author states that none of the drafts presented by their cre- 
ators as creating the presidential system of government indeed did not present such a system of government in a clear form" (p. 231).

The third part of the publication consists of elaborations of Marek Zubik, Mirosław Granat, Jan Wawrzyniak and Andrzej Szmyt, for whom the common denominator is the issue of stability of the constitution.

The first of the mentioned Authors defined his article as an attempt to highlight the importance of some essential phenomena, which are noticeable in the process of everyday application of the RP Constitution (p. 235). He included to them, among others, generally good (to 2015) functioning of the mechanisms of exercising power provided for in the RP Constitution from 1997 and ensuring the adequate status of units in the state, accompanying the formal stabilisation of the text of the Basic Law. He also showed that there exists a permission to redefine constitutional concepts, while preserving the primacy of the presumption of the role of a democratic legislator, "Who - wanting to amend the provisions of the Basic Law - should adopt a law on a change of the constitution after working out the political consensus" (p. 242). He considered as open a question, "whether one was able to work out the mechanisms allowing to state where there are the rational limits of unchangeability of the text of the Constitution from 1997" (p. 242). He also turned attention to the problem of adequacy of Art. 235 of the current constitution in order to pass a totally new Basic Law and to several other questions and detailed proposals concerning specific constitutional solutions (e.g. the issue of a number of MPs and senators, the meaning of Sejm's existence, the mode of giving consent for ratification of an international agreement, the obligatory character of three readings of a Bill, the urgent legislative procedure, correction of the President's political position, a way of regulation of vote of no. confidence, resignation from constitutionalisation of some state bodies or a model of constitutional complaint).

Mirosław Granat considered "understanding a change of the constitution" more interesting than the analysis of individual draft amendments to the RP Constitution (p. 282). In the elaboration titled Rozumienie zmiany Konstytucji RP a tożsamość konstytucyjna he proves that "Art. 235 does not constitute the base to show the difference among types of changes of the constitution, which we intuitively use in science" (p. 259). Through the prism of one of the Constitutional Tribunal's decisions he presents changes in the Constitution of an interpretative character, and referring to the processes connected 
with the European integration he turns attention to the constitutional changes which took place in the result of ratification of the European Treaties according to Art. 90 of the Constitution. He also indicates several possible ways of understanding the concept "constitutional identity". Reflecting on the meaning of "changes of the Constitution" leads the Author to statement that contrary to appearances it is the problem difficult to explain. "By no means it is not only the case of the legislative technique and causing the derogation effect against a legal act as we often see it in the doctrine" (p. 275).

Jan Wawrzyniak concentrates his attention on these proposals for changes in the Constitution, which in his opinion deserve attention and taking action leading to adoption of the changes. He distinguishes among them such "introduction of which is possibly fast necessary, and those, introduction of which can be the subject of further discussion" (p. 285). However, particularly interesting seems to me the catalogue of postulates for changes, separated in his elaboration, which in the Author's opinion should not be realised (e.g. abolition of the parliamentary bicameralism, or decreasing the number of MPs and senators - p. 289). Jan Wawrzyniak puts the thesis that an important cause of lack of politicians' willingness to introduce constitutional changes clarifying the current solutions is that keeping unclear provisions promotes the expansion of their competences and acting on the border of law (p. 290). He illustrates it by a way of regulation of the discharge authority in the Constitution.

The book is closed by the elaboration of Andrzej Szmyt which is dedicated to the way in which the problem of a change of the Constitution was addressed in three draft laws of the Basic Law presented in 2009 by the Ombudsman. After the analysis all the drafts were evaluated as underdeveloped. The Author writes: "They are rather only roughly outlined legislative sketches, which in no. way could be passed" (p. 309).

Each of the problems raised in the texts of the discussed monograph will certainly appear again as the subject of actually an ongoing constitutional discussion, therefore statements of the prominent Polish constitutionalists contained in it should be treated as an important element of this debate.

Krzysztof Eckhardt University of Law and Public Administration in Rzeszow 